BAW-3765-2

U.S. -Euratom Joint

R\&D Program

May 1967

\title{
CEST Brots
}

H.c. $5.00 ;$ ar

CORROSION AND HYDRIDING

OF ZIRCALOY

- Quarterly Technical Progress Report No. 2 -

January to March 31,1967

B. W. Whitaker

Project Manager

C. R. Johnson

Technical Manager

AEC Contract No. AT $\{30-1\}-3765$

B\&W Contract No. 59-3101

Performed for

THE UNITED STATES ATOMIC ENERGY COMMISSION

by

THE BABCOCK \& WILCOX COMPANY

Lynchburg, Virginia 


\section{DISCLAIMER}

This report was prepared as an account of work sponsored by an agency of the United States Government. Neither the United States Government nor any agency Thereot, nor any of their employees, makes any warranty, express or implied, or assumes any legal liability or responsibility for the accuracy, completeness, or usefulness of any information, apparatus, product, or process disclosed, or represents that its use would not infringe privately owned rights. Reference herein to any specific commercial product, process, or service by trade name, trademark, manufacturer, or otherwise does not necessarily constitute or imply its endorsement, recommendation, or favoring by the United States Government or any agency thereof. The views and opinions of authors expressed herein do not necessarlly state or reflect those of the United States Government or any agency thereof. 


\section{DISCLAIMER}

Portions of this document may be illegible in electronic image products. Images are produced from the best available original document. 
THIS PAGE

\section{WAS INTENTIONALLY \\ LEFT BLANK}




\section{SUMMAR Y}

The principal objective of this program is to provide a better definition of operational limitations for Zircaloy fuel cladding. During service in water-cooled reactors Zircaloy cladding will corrode and absorb some of the hydrogen released by the corrosion reaction. The corrosion rate of Zircaloy in high-purity water at pressurized and boiling water reactor temperatures is not excessive, and therefore is not considered a limiting criterion. However, hydrogen adversely affects some mechanical properties of Zircaloy: consequently, excessive hydrogen absorption during service could degrade these mechanical proper. ties to the extent that either the operational conditions or the life of the cladding would have to be curtailed.

The program is divided into two tasks: (1) corrosion and hydriding tests of Zircaloy under heat transfer conditions to determine the quantity of hydrogen absorbed during service, and (2) mechanical property tests of hydrided Zircaloy to determine the effect of bydrogen on cladding properties.

The corrosion and bydriding test loop was operated initially on February 22, 1967. Specimen insertion started March 3, 1967, and was completed March 9, 1967. By April 1, 1967, the heat transfer specimens had accumulated exposures of 560 to 698 hours. The calculated surface heat flux on all specimens is $600,000 \mathrm{Btu} / \mathrm{hr}-\mathrm{ft}^{2}$. The loop has operated continuously since startup at $640 \mathrm{~F}$ and $2250 \mathrm{psi}$. The autoclave section of the loop, housing isothermal specimens at $650 \mathrm{~F}$ and $2950 \mathrm{psi}$, was placed in operation March 9, 1967. The first heat transfer specimen is scheduled for removal May 2, 1967, after a total exposure of 60 days.

Precorroding of specimens in $800 \mathrm{~F}, 500$ psig steam to apply an oxide film and to introduce hydrogen to simulate the condition of cladding at the end of core life began late in the first quarter. A separate 
a utoclave, operating at these conditions and containing specimens for periodic removal and examination to establish the corrosion rate for the Zircaloy specimen material, had been started earlier so that these data would be available to establish the exposure time necessary to reach the desired level of weight gain and hydrogen content. The test specimen data indicated that a 120-day exposure would produce the desired endof-life conditions. After $90 \mathrm{days}$ 'exposure, the nine heat transfer specimens and their associated isothermal specimens were removed for an interim examination. All of the heat transfer specimens had undergone excessive oxidation and were no longer usable. Oher methods of accelerating oxidation and hydriding are being investigated, so that the endof-life specimens can be prepared without the risk of loaing the specimens through excessive oxidation. (Additional specimens are being prepared to replace the lost specimens.) It is expected that test operations will be kept on schedule by using existing specimens for the tests that require early specimen insertion in the loop.

Hydriding of annealed and cold-worked tensile and burst test specimens has been completed through 350 pprn hydrogen content. Roomtemperature tensile testing of these specimens was completed, and preliminary data are presented in Monthly Report No. 6. Elevated-temperature tensile testing of annealed and cold-worked specimens was initiated and tests have been completed through $650 \mathrm{~F}$. A preliminary series of tests was performed to determine the dwell time necessary before testing to yield consistenc tensile strength data. It was found that testing a specimen as soon as it reached test temperature yielded variable and inconsistent results, whereas holding the specimens at test temperature for at least 30 minutes resulted in consistent and reproducible data. This test series is on schedule, and no difficultie should be encountered in maintaining the schedule. 
Page

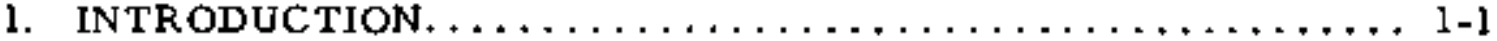

2. CORROSION AND HYDRIDING OF ZIRCALOY UNDER

HEAT TRANSFER CONDITIONS $\ldots \ldots \ldots \ldots \ldots \ldots \ldots \ldots \ldots \ldots \ldots$. $\ldots \ldots \ldots$

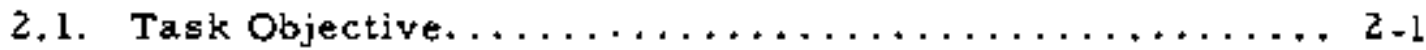

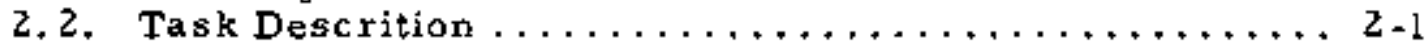

2. 3. Work Accomplished During Report Period ......... 2-3

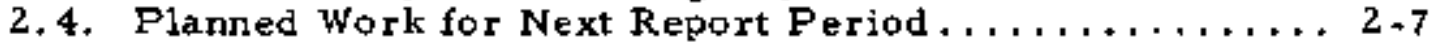

3. EFFECT ON HYDROGEN AND HYDRIDE DISTRIBUTION

ON THE MECHANICAL PROPEPTIES OF ZIRCALOY . . . . . 3-1

3.1. Task Objective...................... 3-1

3. 2. Task Description .................... 3-1

3. 3. Work Accomplished During Report Period ......... 3-2

3. 4. Planned Work for Next Report Period . . . . . . . . . . 3-4

\section{List of Tables}

Table

2-1. Specimens for Corrosion and Hydriding Tests......... 2-8

\section{List of Figures}

Figure

2-1. Heat Transfer Corrosian Test Schedule............. $2-9$

2-2. Specimen Group for End-of-Life Preconditioning ........ 2-9

2-3. Heat Transfer Specimen Assembly Before Exposure..... 2-10

2 -4. Tubular and Strip Control Specimens After Exposure ..... 2-10

2-5. Heat Transfer Specimen Assembly After Exposure ...... 2-11

2-6. Heavily Oxidized Flanges From Heat Transfer Specimens. 2-11

2-7. General View of the Uppex Rack of Specimens After

Exposure ........................... 2-12

2 -8. Close-Up View of Upper Rack After Exposure . . . . . . 2-12

3-1. Effect of Time at Temperature on the $800 \mathrm{~F}$ Tensile Properties of Zircaloy-4 Containing 450 ppm Hydrogen . . 3-5

3-2. Tensile Strength of Annealed Zircaloy-4 as a Function of Temperature...................... $3-6$

3-3. Elongation of Annealed Zircaloy-4 as a Function of Temperature .......................... 3-7

3-4. Tensile Strength of Cold-Worked Zircaloy-4 as a Function

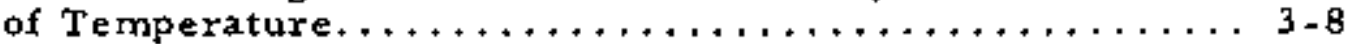

3-5. Elongation of Cold-Worked Zircaloy-4 as a Function of Temperature ........................... 3-9 


\section{i. INTRODUCTION}

Fuel cladding in current pressurized and subcritical-pressure boiling-water reactors is almost always made of the 2 irconium-tin alloys Zircaloy $-Z$ and Zircaloy 4 . These alloys exhibit the strength and corrosion resistance necessary to withstand the rigors of reactor service and nuclear properties that are much more desirable than those of other available materials.

There is a continuing effort to increase the the rmal performance of water reactors; the Zircaloy fuel cladding is thus required to withstand more severe operating conditions for longer periods. Intermittent relocation of fuel elements in the reactor core also adds to the severity of service conditions by introducing a potential high-strain-fatigue factor over and above the cyclic thermal stresses of normal service. While operational experience with Zircaloy has been excellent, some failures of experimental Zircaloy-clad fuel elements indicate that operational limitations should be defined more precisely before committing a Zircaloy-clad core to the demanding conditions of advanced reactor designs. The goal of this program is better definition of operational limitations for Zircaloy fuel cladding.

The program is divided into two experimental tasks:

1. Corrosion and hydriding tests of Zircaloy under heat transfer conditions.

2. Determination of the effects of hydrogen and hydride distribution on the mechanical properties of Zircaloy.

During the second quarter, the corrosion and hydriding test loop was started and all specimens were inserted. By April 1, 1967, heat transfer specimens had accumulated from 560 to 698 hours' exposure at $600,000 \mathrm{Btu} / \mathrm{hr}-\mathrm{ft}^{2}$ heat flux. The loop and the autoclave section operated continuously from startup to the end of the quarter. 
Preparation of the pre-oxidized and hydrided specimens simulating end-of-life conditions was terminated after 90 days' exposure of the specimens in $800 \mathrm{~F}, 500 \mathrm{psi}$ steam. Nine of the heat transfer specimens had undergone excessive oxiclation and were no longer usable. Other methods of preparing these specimens are being evaluated.

A series of tests was performed to establish the dwell time at testing temperature necessary before testing to yield consistent tensile strength data. Tensile testing of specimens containing up to $350 \mathrm{ppm}$ hydrogen was completed through the $650 \mathrm{~F}$ tests. Additional hydrided specimens are available for testing at $750 \mathrm{~F}$ and $800 \mathrm{~F}$.

During the next guarter, the first heat transfer specimen will be removed from the corrosion test loop after a total exposure of 60 days; examination of this specimen will begin. A suitable method will be developed for accelerated hydriding and oxidizing of the heat transfer specimens to simulate the surface oxide and hydrogen content of fuel cladding near the end of its service life. These specimens will be prepared, and at least one will be inserted in test. Artificial hydriding of tensile and burst test specimens will be completed, and most, if not all, of the tensile testing will be performed. Burst testing is scheduled to begin during the third quarter. 


\section{CORROSION AND HYDRIDING OF ZIRCALOY \\ UNDER HEAT TRANSFER CONDITIONS \\ (D. W, Koch and M. M. Rubright)}

\section{1. Task Objective}

This task will provide quantitative data on corrosion and hydriding rates for zirconium alloy fuel cladding under conditions simulating those expected in advanced water reactor service. Zircaloy- 2 and Zircaloy-4 hydriding characteristics will be compared, and an abbreviated test in borated water will be performed to determine whether the chemical poison addition has any gross effects on corrosion and hydriding.

\section{2. Task Description}

Under heat transfer conditions prevalent in eurrent and advanced water reactor designs, fuel cladding surface temperatures can exceed $650 \mathrm{~F}$, and the temperature gradient through the cladding can be as high as $150 \mathrm{~F}$; thus the inside surface temperature of the cladding can be in excess of $800 \mathrm{~F}$. Corrosion of the cladding under a temperature gradient might proceed at a rate somewhat greater than that predicted by is othermal tests at the bulk water temperature. Similarly, absorption of some of the hydrogen released during the corrosion reaction should increase with the increased corrosion rate. However, hydrogen migrates down a temperature gradient in zirconium and concentrates in the lower-temperature region. In the case of fuel cladoing operating under bigh heat flux conditions, the lower-temperature region is also the corroding surface where bydrogen is being introduced. This artivity tends to promote hydrogen concentration at the outside surface of the cladding, and zirconium hydride will precipitate in this location when the solubility limit is reached. The high concentration of hydrogen at the surface of the cladding should inhibit further hydrogen absos' tion, and the precipitated zirconium hydride should have some effect on 
the mechanical properties of the cladding. This program is designed to provide quantitative answers to these suppositions.

In a previous program at B\&W, Zircaloy-4 specimens exposed in $630 \mathrm{~F}, 2200 \mathrm{psi}$ water at a calculated surface heat flux of $450,000 \mathrm{Btu} /$ hr- $\mathrm{ft}^{2}$ (about $650 \mathrm{~F}$ surface temperature) corroded at a slightly higher rate than did the $630 \mathrm{~F}$ is othermal specimens exposed in the same corrosion loop.' Hydrogen absorption by the heat transfer specimens, how ever, was appreciably higher than that under isothermal conditions. This result led to speculation that (1) the hydrogen absorption rate of Zircaloy- 4 under the local boiling test conditions is much greater than the rate under isothermal or non-boiling conditions, (2) the presence of a hydride layer or zone of high hydrogen concentration enhances rather than inhibits hydriding, or (3) there existed an extraneous source of hydrogen (such as a contaminant in the helium cover gas used inside the tubular specimens\}. The current program is expected to resolve the question.

In the test program covered by this task, Zircaloy-2 and Zircaloy4 tubing will be exposed to $640 \mathrm{~F}$ water flowing past the specimen at approximately 13 feet per second. The specimens will be internally heated over 6 inches of their length with special single-ended electrical heaters producing a calculated surface heat flux on the specimen of $600,000 \mathrm{Btu} / \mathrm{hr}-\mathrm{ft}^{2}$. An intentional hot $\mathrm{z}$ ane will be installed at the end of the heated length to inhibit hydrogen migration to the cooler, unheated portion of the specimen. Precautions will be taken to inhibit introduction of hydrogen to the specimens by means other than corrosion during the test.

Five test stations are situated in parallel legs of the test loop so that a test specimen can be isolated and removed from test without interfering with the other four specimens. Metallographic examination will be used to determine oxide film thicknesses and hydride distribution, and the hydrogen concentration of the specimens will be determined by vacuum-extraction. Samples for hydrogen analysis will be taken from various axial positions to evaluate axial migration of hydrogen and selective hydriding of the specimens. Radial hydrogen distribution will be determined by metallographic methods and by analyzing samples of machine chips removed from the surface of the specimen during 
successive turnings. Weight change and hydrogen absorption values will be compared with similar data from previous experiments and with data from isothermal control specimens exposed in the loop and in a connected autoclave. The autoclave will be operated at a temperature close to that of the surface of the heat transfer specimens.

Specimens will be removed and examined at intervals during the 180-day exposure to permit evaluation of both corrosion and hydrogen absorption as a function of exposure time. To evaluate the insulating effect of a substantial corrosion film on corrosion and hydriding rates, several heat transfer and control specimens will be pre-corraded to simulate the end-of-1ife condition of fuel cladding after service in a pressurized water reactor. Corrodent conditions during this initial 180 -day test series will be similar to those of an unpoisoned pressurized water reactor.

The second test series will be of 30 days' duration. Specimens from the 180-day test will be continued in the 30-day test and some virgin specimens will be added. Corrodent conditions for the second series will simulate those of a pressurized water reactor with borated water. Specimen evaluations will be similar to those of the 180-day test, with emphasis on a determination of any gross effects on corrosion and hydriding owing to the altered corradent conditions.

2. 3. Work Accomplished During Report Period

2. 3. 1. Summary

The corrosion and hydriding test loop was first operated on February 22, 1967, and insertion of the five heat transfer specimens was completed by March 9. Operation has been continuous since startup, with all specimens producing a calculated $600,000 \mathrm{Btu} / \mathrm{hr}-\mathrm{ft}^{2}$ heat flux in the $640 \mathrm{~F}, 2250 \mathrm{psi}$ loop water. The first heat trangfer specimen is scheduled for removal May 2, 1967, after a total exposure of 60 days.

Precorroding specimens in $800 \mathrm{~F}, 500 \mathrm{psig}$ steam to apply an oxide film and to introduce hydrogen to simulate the condition of cladding at the end of core life had begun late in the first quarter. After 90 days ${ }^{\dagger}$ exposure, the nine heat transfer specimens and theif associated isothermal specimens were removed for an interim examination. All of the heat transfer specimens had undergone excessive oxidation and were no 
longer usable. Other methods of accelerating oxidation and hydriding are being invertigated, so that the end-of-life specimens can be prepared without the risk of losing the specimens through excessive oxidation. (Additional specimens are being prepared to replace the lost specimens.) It is expected that test operations will be kept on schedule by using existing specimens for the tests that require early specimen insertion in the loop.

\section{3. 2. Loop Operation}

The test loop modifications we re completed and operation was started on Eebruary 22, 1967, Specimen insertion was started March 3, 1967, and was completed on March 9. By April 1, 1967, the heat transfer specimens had accumulated exposures of 560 to 698 hours. The calculated heat flux on all specimens is $600,000 \mathrm{Btu} / \mathrm{hr}-\mathrm{ft}^{2}$, and the bulk coolant operating conditions are $640 \mathrm{~F}$ and $2250 \mathrm{psi}$. The loop has operated continuously since startup, and all specimens have performed satisfactorily under continuous exposure at the calculated heat ratings. The autoclave section of the loop, containing isothermal specimens at $650 \mathrm{~F}$ and $2950 \mathrm{psi}$, was placed in operation March 9, 1967. These specimens had accumulated 562 hours exposure by April 1, 1967. The schedule was modified so that the first specimen to be removed will have been exposed for 60 days by the May 2, 1967, removal date (shown in Figure 2-1). The specimen identifications and descriptions listed in Table 2-1 correspond to the current achedule.

\section{3. 3. End-of-Life Specimen Preparation}

Preliminary work on this project during the latter part of 1966 indicated that exposing specimens to $800 \mathrm{~F}, 500$ psig steam would accelerate the formation of an oxtde film and the accompanying hydrogen absorption enough to simulate, in an acceptably short time, the condition of cladding at the end of core life. The results of a series of 10 to 20 days of autoclave tests (with an accumulated total of 40 days) indicated that formation of the desired end-of-life condition could be established in a 120-day period with $800 \mathrm{~F}, 500 \mathrm{paig}$ steam.

On December 22, 1966, a series of nise specimen groups - seven of Zircaloy-4 and two of Zircaloy-Z-were loaded on a rack in an autoclave and exposed to $800 \mathrm{~F}, 500 \mathrm{psig}$ steam. This was the number 
of specimens required to complete the projected loop testing for this project. Each specimen group comprised one 4-inch and one 2 -inch unsealed tubular specimen; two plate specimens formed by splitting and then flattening a 2 -inch-long tube; a sealed 6 -inch-long tubular specimen: and a sealed 15 -inch tubular specimen which has a z-inch-diameter, 1/4-inch-thick flange welded to the tube 2-7/16 inches from one end. Such specimens are labeled $B$ through $G$ in Figure $2-Z$. Two sealed sections of each specimen were slated for insertion in the heat transfer configuration of the test loop, and the unsealed tubular and plate sections were assigned to serve as isothermal specimens. The sealed specimens were suspended individually from a series of bolts inserted in two tiers in the lower rack, as shown in Figure 2-3. The second rack held the unsealed specimens and the flat specimens, as shown in Figure $2-4$.

The autoclave used to produce the end-of-life condition was constructed of type- 304 atainless steel, was 5.06 inches in inside diameter and 7.5 feet deep, and had a volume of 29.7 liters. It was electrically heated, and the temperature was controlled from a well-type thermocouple located just above the top plate of the upper rack, about 6 inches above the uppermost array of sugpended sealed specimens. The pressure was recorded throughout the exposure period.

On March 23, 1967, after 90 days' exposure, power to the autoclave heaters was turned off and the autoclave was allowed to cool to permit an interim examination. A residual pressure of 250 psig was present after almost complete cooldown. Analysis of this gas, primarily hydrogen, revealed the presence of $0.064 \%$ oxygen, $0.03 \%$ nitrogen, and $0.015 \%$ methane. It was assumed that the nitrogen and oxygen were the results of slight leakage of air during sampling; the methane was astumed to be the product of hydrolysis of carbides present in either the zirconium or the stainless steel racks. The residual pressure was released slowly, and the autoclave was opened.

Figure 2-4 thows the appearance of the upper rack, Some difficulty was experienced at first in removing the lower rack. Figure 2-5 is a general view of the lower rack, and Figure $z-6$ is a close-up view of the remains of the heat transfer specimens. The sealed specimens had almost completely degenerated into oxide powder, and only the 
flange material remained generally intact, although three flanges had degenerated into small fragments and one of those remaining exhibited flaking. There was a large amount of fine powder in addition to that shown in Figure 2-6.

The specimens which were in the upper rack during the exposure period had been affected less than the sealed sections suspended from the lower rack. Figure 2-7 is a general view of the specimens in the rack after removal, and Figure $2-8$ is a close-up of the lower portion of this rack. The tubular specimens were heavily oxidized. One section was blistered and had split. It was theorized that the upper stainless steel plate expanded during the test and allowed the short section to slip out of its locating hole. During cooldown the plate contracted to (approximately) its original position and thus placed a stress on the misaligned tube and caused it to split. The tubular sections were tightly sealed in their location holes and have not been removed,

The plate specimens were removed and weighed. The weight increase of the 18 specimens varied from 111.8 to $262.6 \mathrm{mg} / \mathrm{dm}^{2}$, with an average weight gain of $162.1 \mathrm{mg} / \mathrm{dm}^{2}$. These weight gains are close to those predicted for a 90-day exposure using 40-day data as the basis for extrapolation. Analysis of the plate specimens indicates a hydrogen content of about $1000 \mathrm{ppm}$.

In a separate test, two similar Zircaloy- 2 specimens had been exposed to the same operating conditions for 14 days when the excess oxidation of specimens in the other autoclave was discovered. These specimens were removed for examination, and their weight gains were close to predicted values.

The cause of the gross attack on the specimens has not been identified. One suggestion is that a reaction occurred during the latter part of the test that was different from that present in the earlier part. This theory states that the environment at the start of the test was steam, and that this changed as the test continued because of the hydrogen formed during the corrosion. The increasing hydrogen concentration would not be obvious because the pressure would remain constant. Past experience shows that Zircaloy absorbs hydrogen from a hydrogen atmosphere more rapidly than from a steam environment. This theory is supported by the results of chemical analyses of the plate specimens, 
which indicate that their hydrogen content is much higher than can be accounted for by the hydrogen released by their own corrosion. There was more wate $x$ originally present in the autoclave than was required for the desired corrosion rate, and water was still present in the autoclave at the end of the test. The time required to achieve the concentration of hydrogen needed for a change in the type of hydrogen absorption to occur is not known, but the results of other tests performed on this project indicate that it must have been greater than 20 days. In any event, at the end of the 90-day exposure, most of the autoclave atmosphere was hydrogen.

Other methods of expeditiously attaining end-of-core-life oxide thicknesses and hydrogen concentrations in the cladding are being evaluated. The schedule was modified to provide more time for end-oflife specimen preparation, and additional material was procured for manufacturing specimens to replace those lost during the preconditioning treatment.

\subsection{Planned Work for Next Report Period}

Loop operation will continue; the first planned outage will be on May 2, 1967. At that time, specimen 4-13 will be removed, along with control specimens from the loop and autoclave. Normally, flow in the loop would not be curtailed during specimen removal, because each specimen is located in a separate test leg that can be isolated from the system. However the loop does require some preventive maintenance that will necessitate depressurizing the system. The loop will be restarted in the normal manner, and the standard precautions will be taken to minimize the cycling effects on specimen performance. 
Table 2- L. Specimens for Corrosion and Hydriding Tests

\begin{tabular}{|c|c|c|}
\hline $\begin{array}{l}\text { Specimen } \\
\text { number }\end{array}$ & $\begin{array}{l}\text { Pre-test } \\
\text { condition }\end{array}$ & $\begin{array}{c}\text { Exposure. } \\
\text { days }\end{array}$ \\
\hline \multicolumn{3}{|c|}{ Zircaloy -4 Series } \\
\hline $2 r-4 \cdot 1$ & 750 F pre-film & $180-$ test 1 \\
\hline$Z r-4-2$ & $750 \mathrm{~F}$ pre-film & $\begin{array}{r}180-\text { test } l \\
30-\text { test } 2\end{array}$ \\
\hline$Z_{r-4-4}$ & $750 \mathrm{~F}$ pre-film & 120 - test 1 \\
\hline $2 r-4=13$ & 750 Fpre-film & $60-$ test 1 \\
\hline$Z I-4-5$ & 750 F pre-film & $30-$ test 1 \\
\hline $2 r-4-7$ & End of life & 45 - test 1 \\
\hline $2 r-4-8$ & End of life & $30-$ test 1 \\
\hline$Z r-4-9$ & End of life & 15 - test 1 \\
\hline$Z r-4-11$ & End of life & $30-$ test 2 \\
\hline$Z r-4-10$ & End of life & $30-$ test 2 \\
\hline \multicolumn{3}{|c|}{ Zircaloy- 2 Series } \\
\hline$Z_{5}-2-1$ & 750 F pre-film & $\begin{array}{r}180-\text { test } 1 \\
30-\text { test } 2\end{array}$ \\
\hline $2 r-2-5$ & End of life & 45 - test 1 \\
\hline$Z_{\mathbf{r}}-\mathbf{Z}-7$ & End of life & 15 - test 1 \\
\hline$Z r-2-4$ & End of life & $30-$ test 2 \\
\hline
\end{tabular}


Figure 2-1. Heat Transfer Corrosion Test Schedule

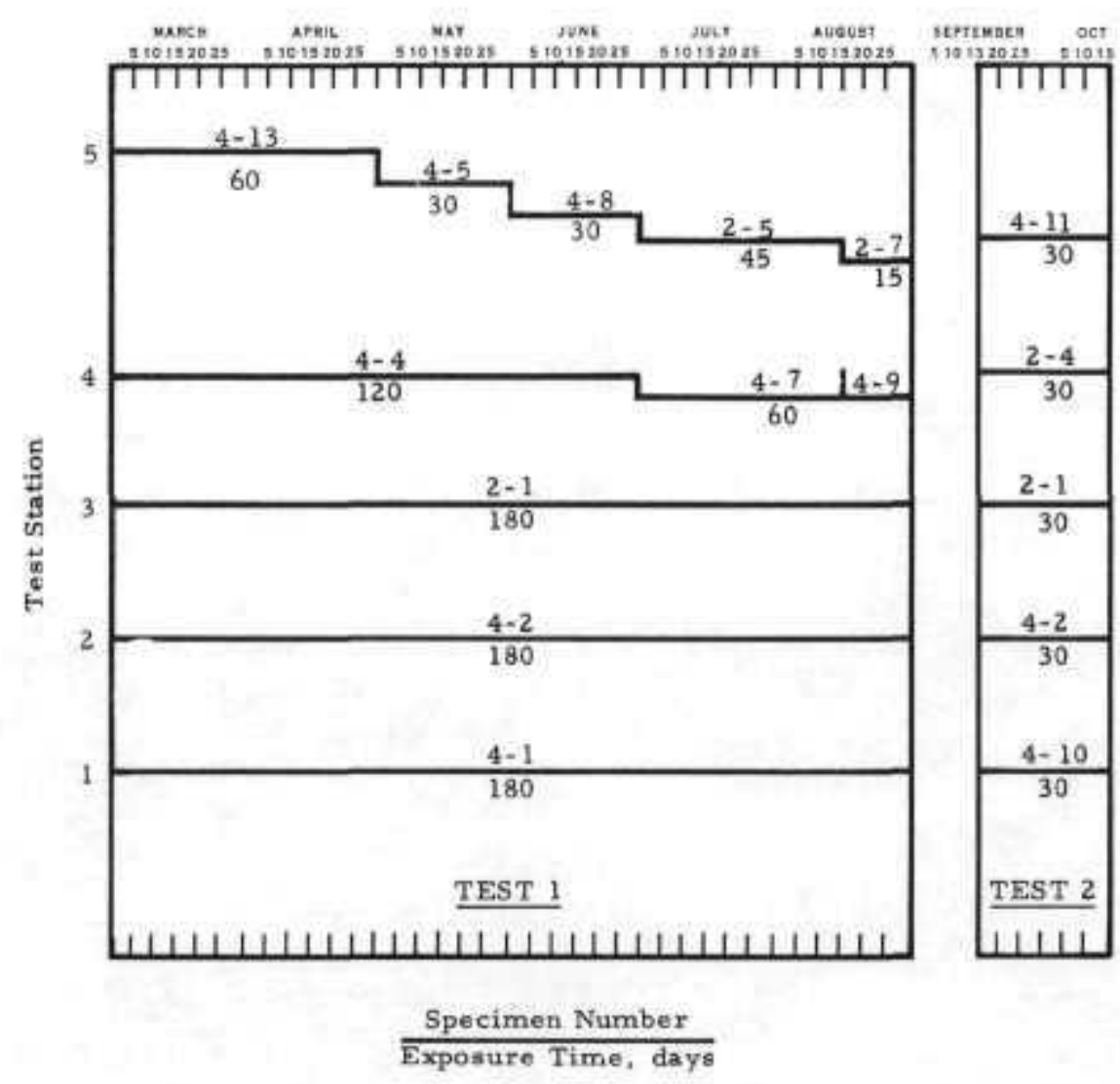

Figure 2-2. Specimen Group for End-of-Life Preconditioning

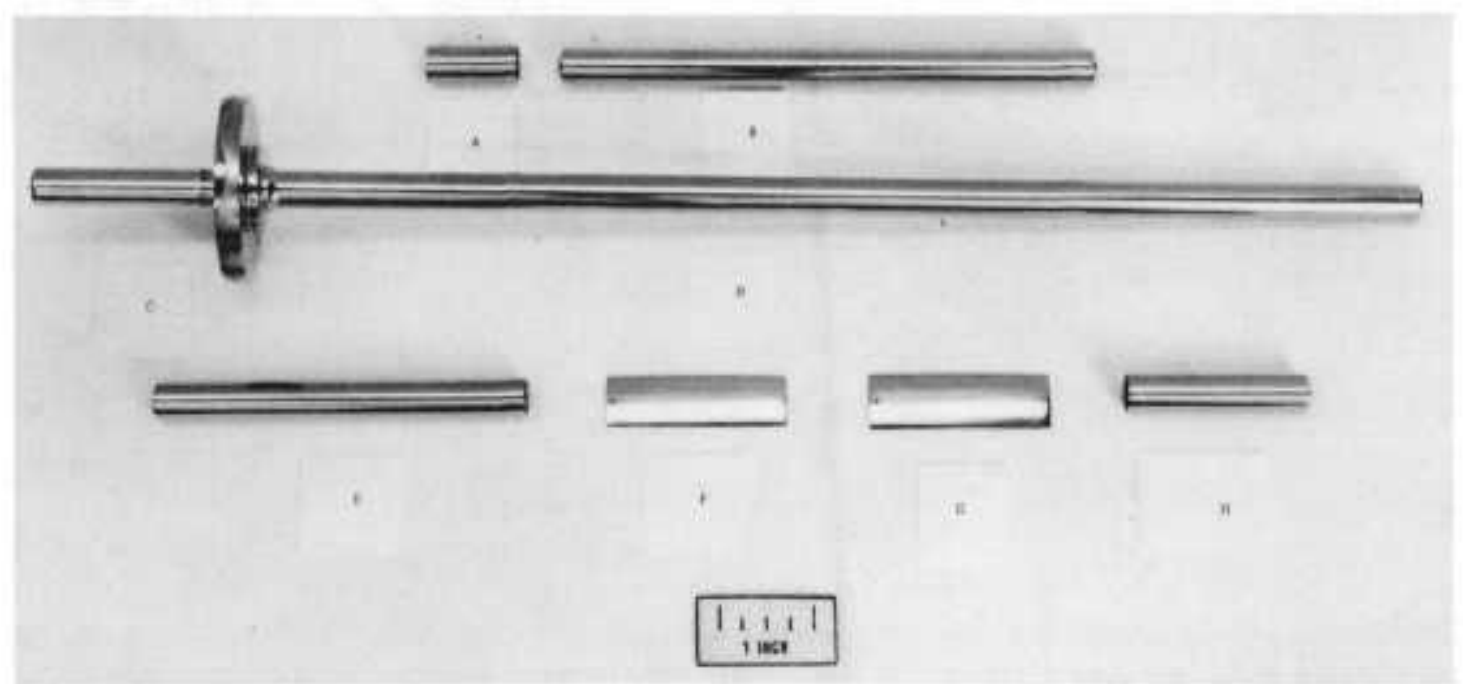


Figure 2-3. Heat Transfer Specimen Assembly Before Exposure

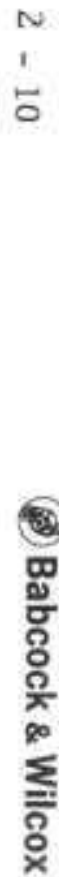

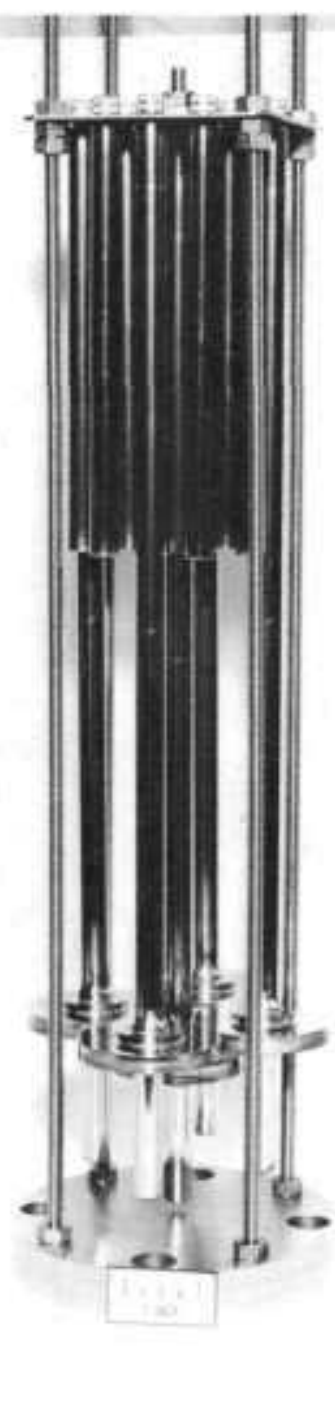

Figure 2-4. Tubular and Strip Control Specimens After Exposure

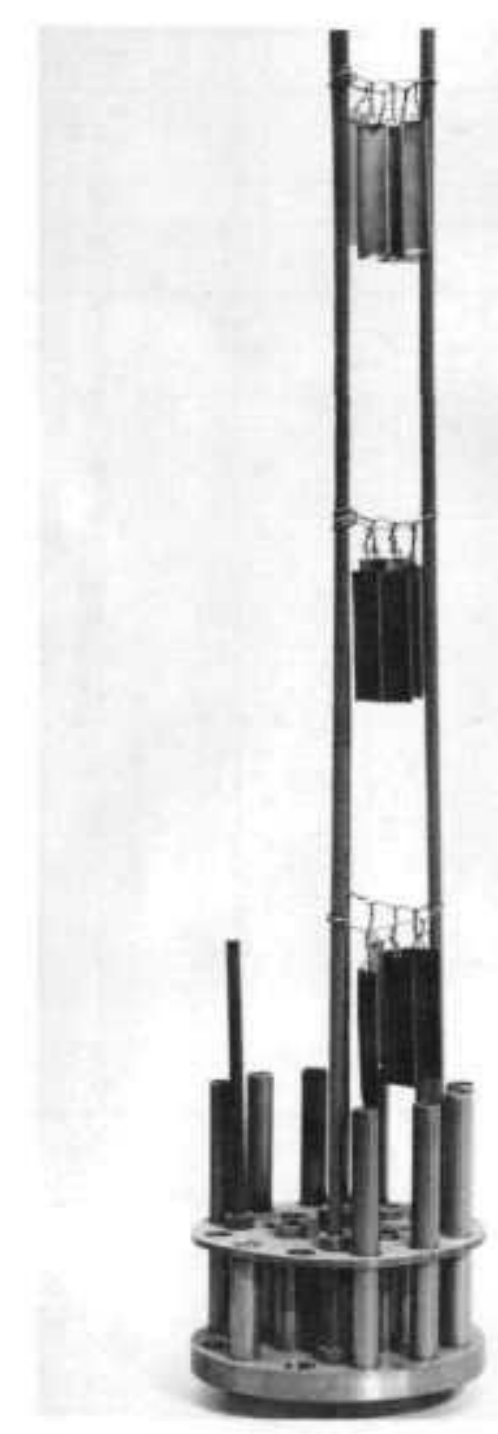


Figure 2-5. Heat Transfer Specimen Assembly After Exposure

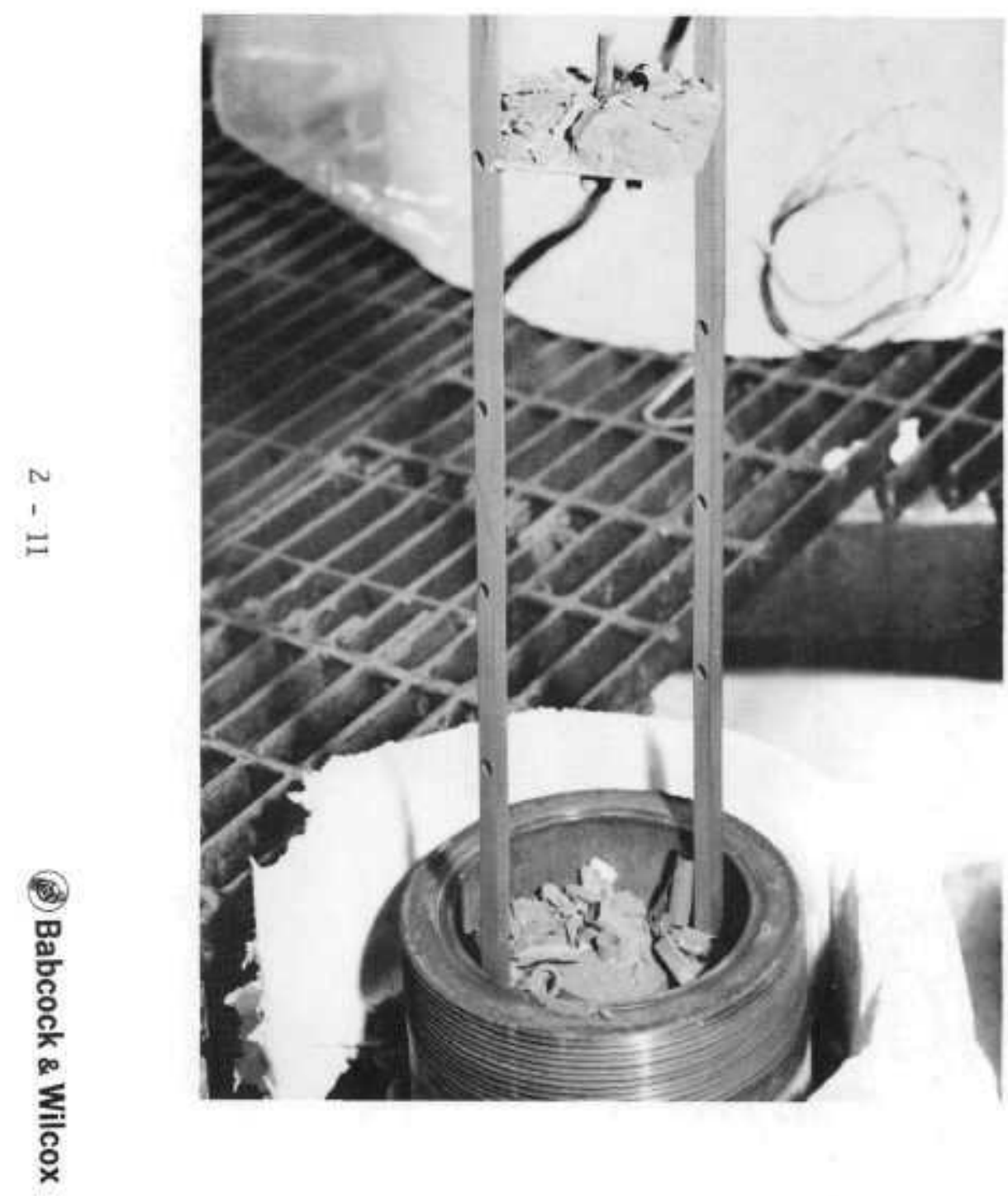

Figure 2-6. Heavily Oxidized Flanges From Heat Transfer Specimens

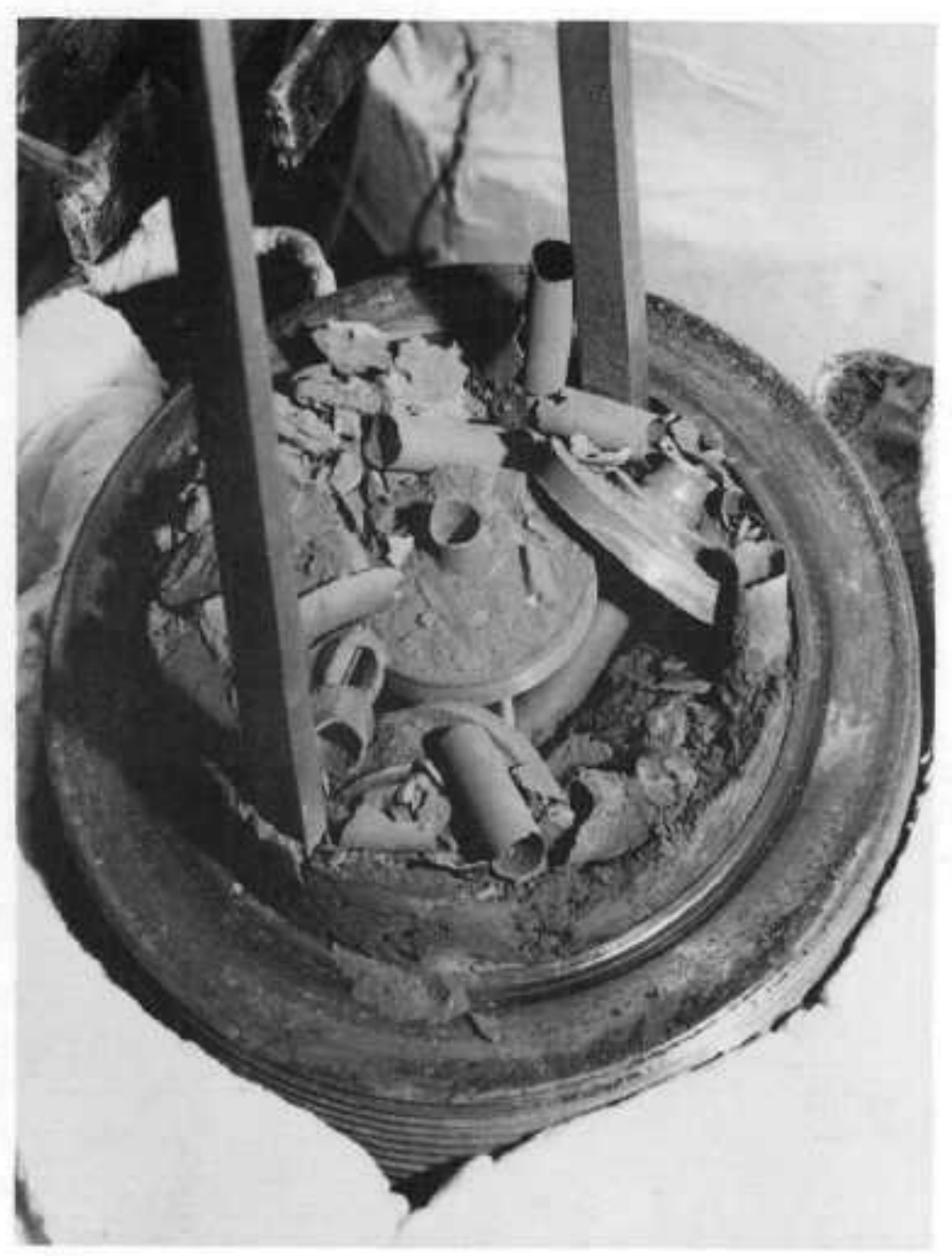


Figure 2-7. General View of the Upper Rack of Specimens After Exposure

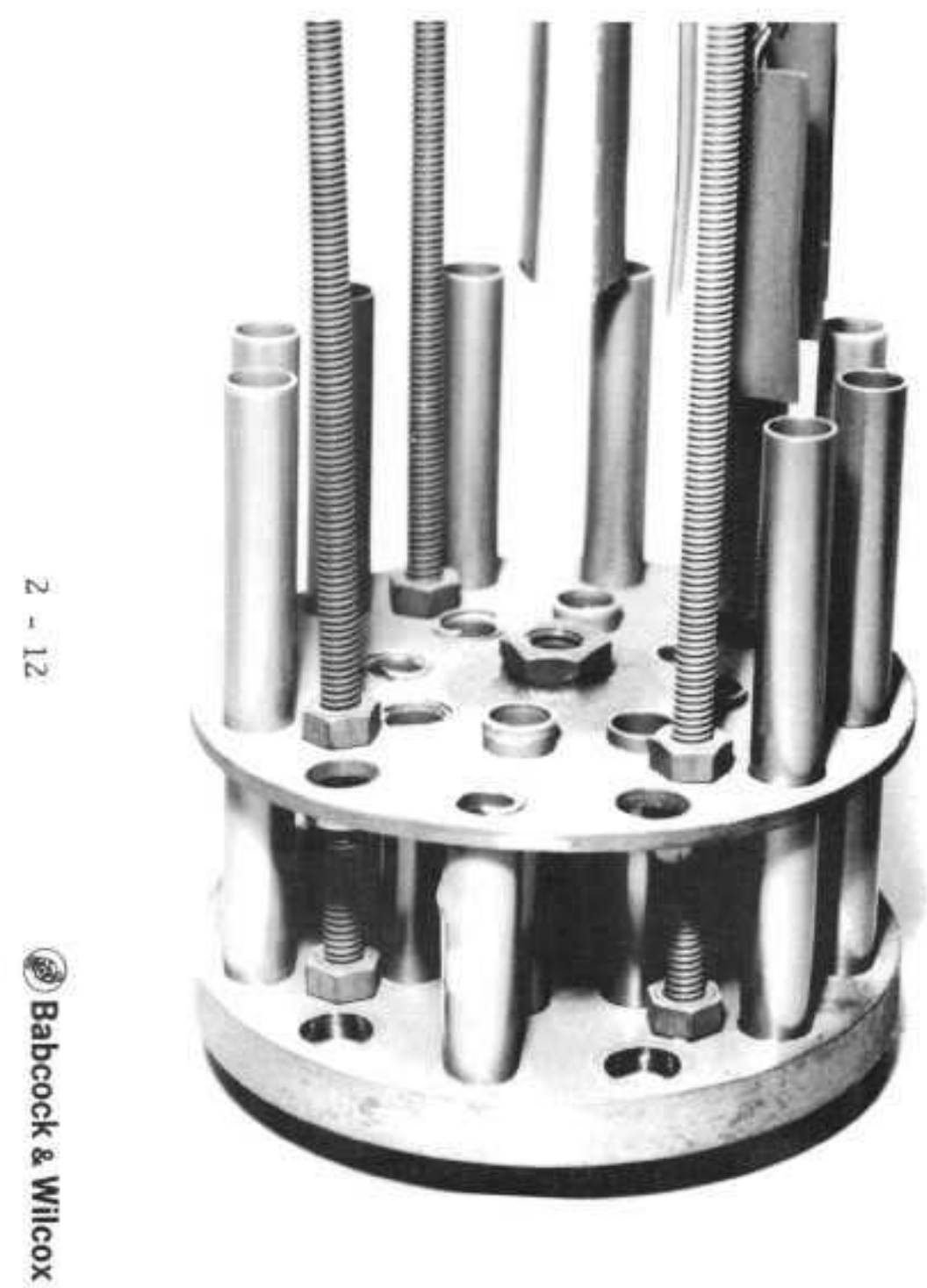

Figure 2-8. Close-Up View of Upper Rack

After Exposure

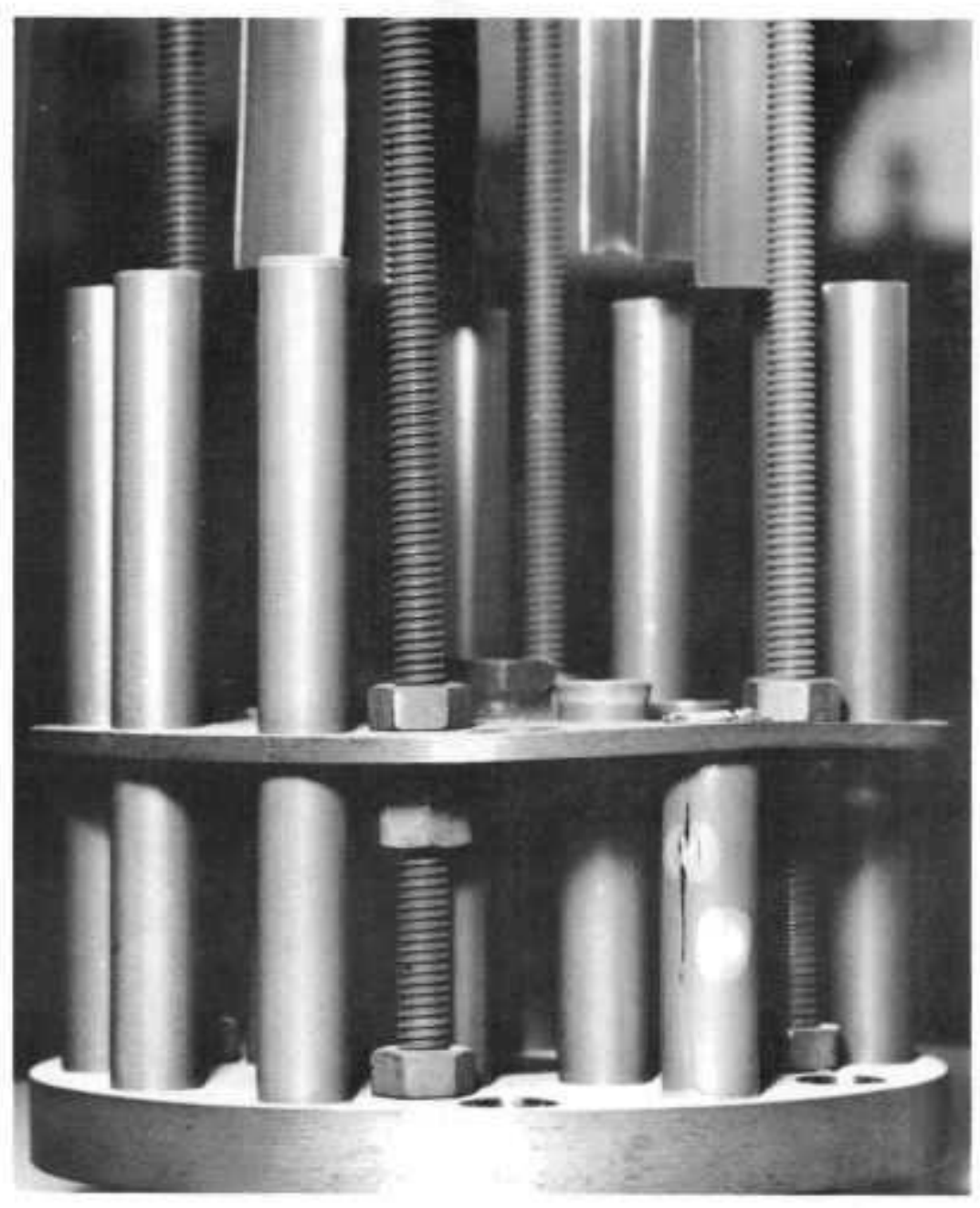




\section{EFFECT OF HYDROGEN AND HYDRIDE DISTRIBUTION ON THE MECHANICAL PROPERTIES OF ZIRCALOY \\ (A. L. Lowe, Jr.)}

\section{1. Task Objective}

This task will determine the effect of hydrogen, in the concentration range from 150 to 1000 parts per million, on the tensile and burst properties of Zircaloy tubing. Tensile tests will be performed at temperatures ranging from room temperature to $800 \mathrm{~F}(427 \mathrm{C})$ on hydrided specimens of coldworked and annealed Zircaloy-4. A similar series of specimens will undergo burst testing at room temperature.

\section{2. Task Description}

The Zircaloy tubing specified for fuel cladding service in pressurized and boiling water reactors is expected to exhibit and retain tensile properties above those of annealed material. During operation, however, the fuel cladding is subjected to the hardening effects of ra-

diation, the annealing effects of prolonged exposure at elevated temperature, and the ill-defined effects of increased hydrogen content caused by absorption of part of the corrosion*released hydrogen. Operational and lifetime limitations have been placed on Zircaloy-clad elements because of the possible effects of hydrogen on the mechanical properties necessary to sustain cladding integrity. The limitations are artificial in the sense that they did not result from failure experience or from systematic experimental determinations of the effects of hydrogen on these properties.

During a previous experimental program at B\&W it was shown that hydrogen, in the form of a hydride case up to about 0.001 inch thick or uniformly distributed at a concentration up to about $350 \mathrm{ppm}$, has no significant effect on the tensile or burst strength of 0.420 -inch-diameter, 0.025-inch-wall, cold-worked Zircaloy-4 tubing. ${ }^{2}$ Tensile 
elongation values for hydrided specimens we re not significantly lower than elongation values for unhydrided specimens. The innocuous effect of hydrogen on strength and longitudinal ductility indicates that limitations on allowable hydrogen concentrations have little experimental or practical basis. Ductility during burst testing, however, was appreciably less for uniformly hydrided specimens than for unhydrided specimens. The appearance of the fracture in the burst specimens clearly showed the embrittling effects of precipitated hydride in Zircaloy. In the cases of the unhydrided specimens and the electrolytically hydrided specimens where the hydrogen is cancentrated in a layer or case at the outside surface, considerable deformation occurred before fracture. In the specimens with uniformly distributed hydride, very little deformation was evident, and the fracture propagated nearly the full length of the specimen. However, it is not practical to base operational limitations on the fact that transverse ductility at room temperature is appreciably decreased by precipitated zirconium hydride, because of the considerable successful operating experience $w$ ith the cladding material that contains more than 100 ppm hydrogen.

The goal of this series of tests is to provide more precise data on the effects of hydrogen on the tensile and burst properties of cur rently available Zirealoy-4 fuel cladding tubing. Specimens containing up to $1000 \mathrm{ppm}$ hydrogen will be tested, and the resultant data will be evaluated with respect to hydride morphology and the original condition of the specimen. These tests $w$ ill provide data for evaluating strength and ductility as functions of hydrogen content and temperature.

3. 3. Work Accomplished During Report Period

3. 3. 1. Summary

Hydriding of annealed and cold-worked tensile and burst test specimens has been completed through 350 ppm hydrogen content. Foom-temperature tensile testing of these specimens was completed, and preliminary data were included in Monthly Report No. 6. Elevatedtemperature tensile testing of both annealed and cold-worked specimens was started, and tests have been completed through $650 \mathrm{~F}$. A preliminary series of testo was performed to determine the dwell time nec. essary before testing to yield consistent tensile strength data. It was 
found that testing a specimen as soon as it reached test temperature yielded variable and inconsistent results, whereas holding the opecimens at test temperature for at least 30 minutes resulted in consistent and reproducible data.

\section{3. 2. Specimen Preparation}

During the last report period, it was noted that aging the hydrided specimens before tensile testing affected yield strength. Further experiments were performed during this period to establish the aging or dwell time at testing temperature required to stabilize the specimen so that the test results would be consistent. It was suspected that a finite time period was required to dissolve precipitated hydrides, and that testing before dissolution to the solubility limit at the test temperature would result in non-reproducible or erroneous results.

A series of specimens was hydrided to a level of $450 \mathrm{ppm}$ hydrogen and then tested at $800 \mathrm{~F}$ after an aging treatment (at $800 \mathrm{~F}$ ) of either 25 minutes or 24 hours. The effect of the aging treatment was negligible; however, there is an effect of dwell time at the testing temperature before testing the specimen. From these test results, shown in Figure 3-1, it was established that an aging treatment is not required and that a dwell time of 30 minutes before testing is adequate to stabilize the specimen so that reproducible data can be obtained.

\subsubsection{Tensile Test Results}

Specimens in the as-received condition and specimens containing 150 and 350 ppm hydrogen were tested at temperatures up to 650 F. Data from these tests are plotted in Figures 3-2 to 3-5. Figure 3-2 show the effect of test temperature on the strength of annealed Zircaloy -4 containing 20, 150, and 350 ppm hydrogen. The elongation data for these tests are plotted in Figure 3-3. There is no significant effect of up to 350 ppm hydrogen on the yield or ultimate tensile strength of Zircaloy-4. Elongation values at low temperature show the embrittling effect of hydrogen on Zircaloy; however, the effect diminishes to insignificance as temperature is increased. Figure 3-4 shows the effect of test temperature on the strength of cold-worked Zircaloy-4 containing 20,150 , and $350 \mathrm{ppm}$ hydrogen. The elongation data for these tests are 
plotted in Figure 3-5. There is no significant effect of up to $350 \mathrm{ppm}$ hydrogen on the yield or ultimate tensile strength of cold-worked Zircaloy-4. Elongation values at low temperatures show the embrittling effect of hydrogen on cold-worked Zircaloy-4.

3. 4. Planned Work for Next Report Period

Hydriding of all specimens will be completed. Tensile testing will be continued, and it is anticipated that all tensile testing will be completed. The burst facility $w$ ill be assembled and the initial testing of specimens to check the equipment will begin.

\section{LEGAL HOTICE}

Thil dacument wal prapared under the opan nar nalg of tha Uniud Skated Arothic Entroy Commintion purwust to the Joint Retetreb and Develogmept Pragram

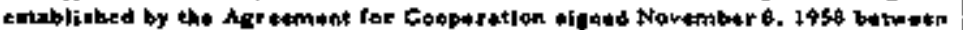

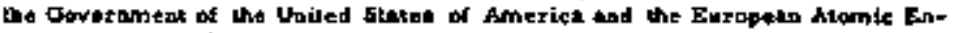

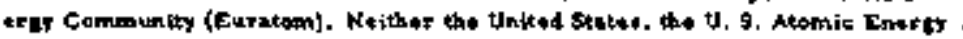

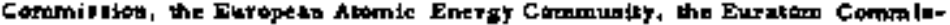

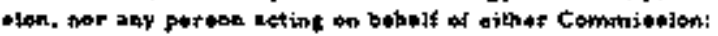

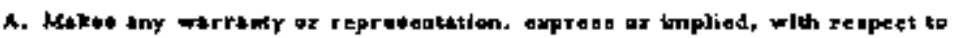

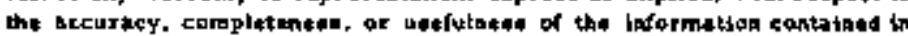

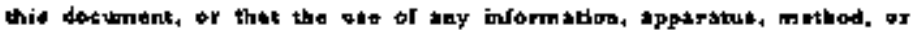
procese drecloned in thio socumant may aol inf hage privetely owned righto: or

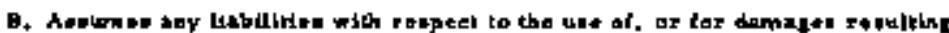

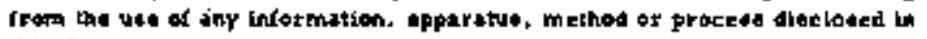
thil doctersent.

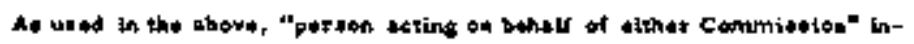

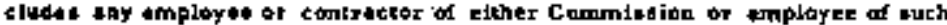

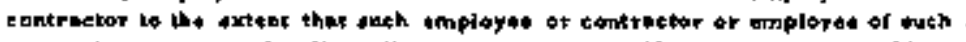

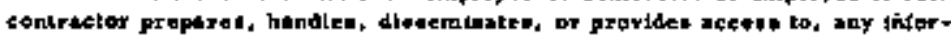

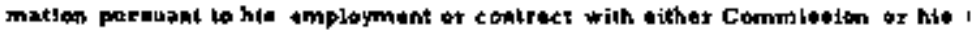
imploythot with euch contracter. 
Figure 3-1. Effect of Time at Temperature on the $800 \mathrm{~F}$ Tensile Properties of Zircaloy-4 Contajning 450 ppm Hydrogen

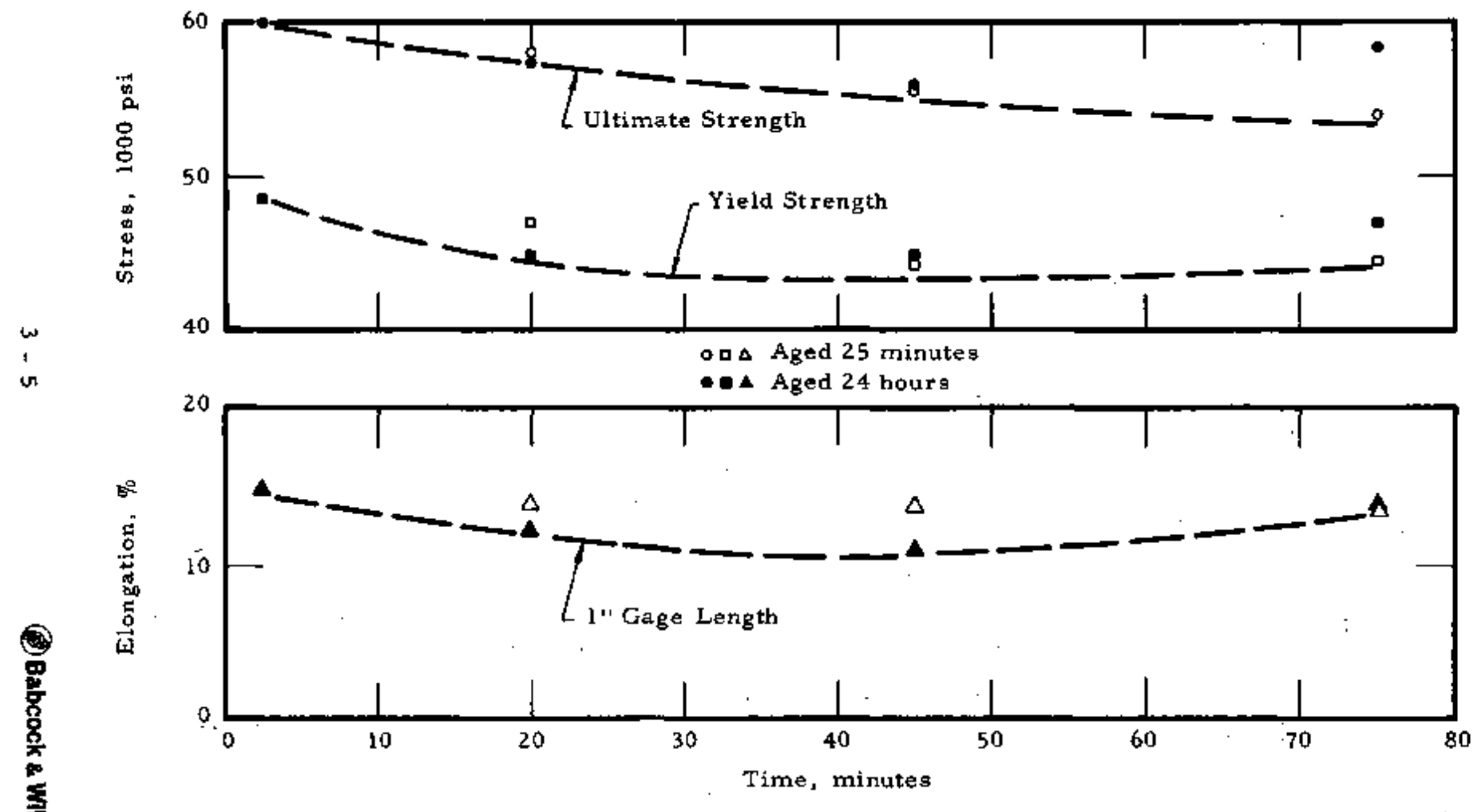


Figure 3-2. Tensile Strength of Annealed Zircaloy-4 as a Function of Temperatur $\theta$
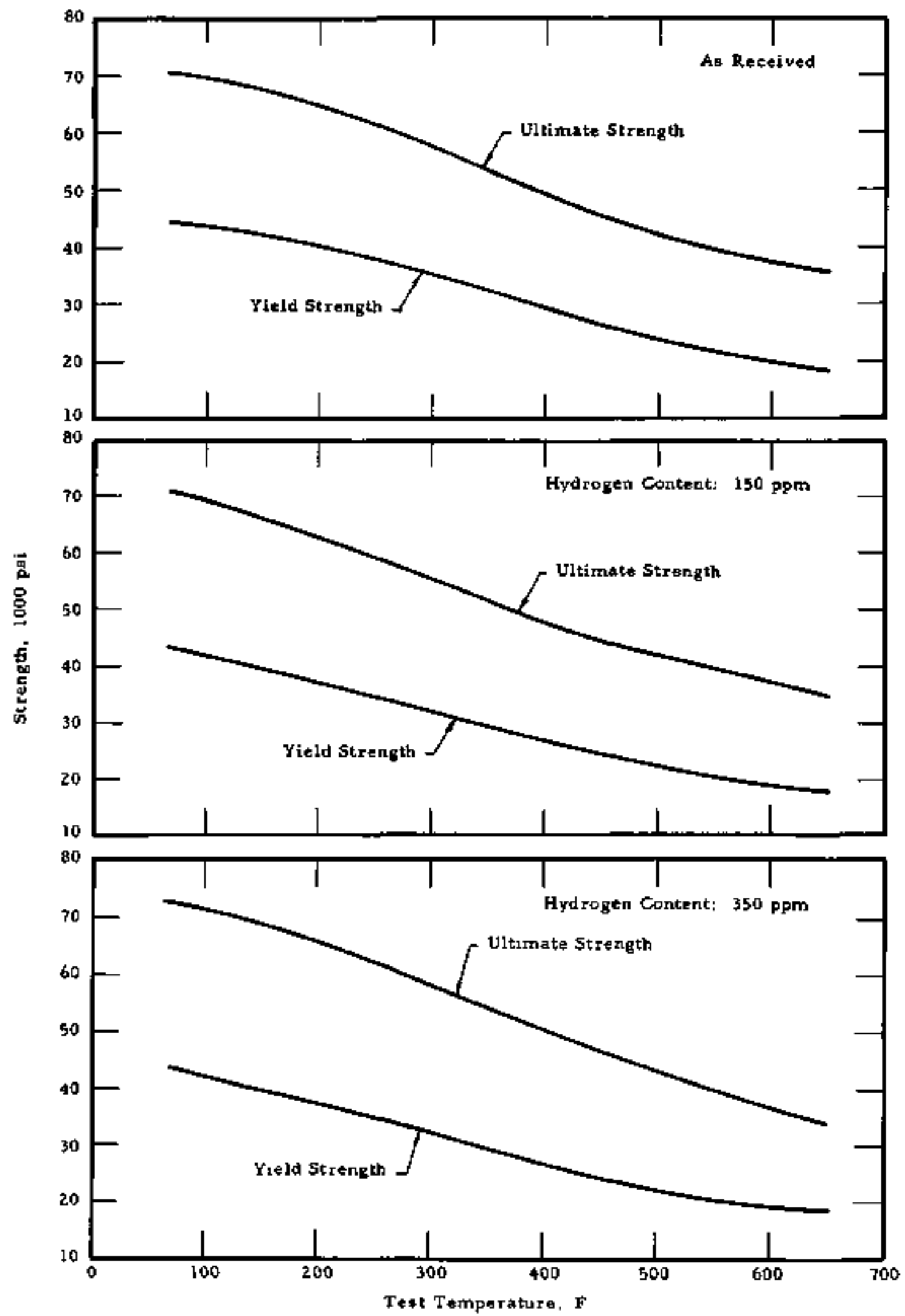
Figure 3-3. Elongation of Annealed Zircaloy-4 as a Function of Temperature

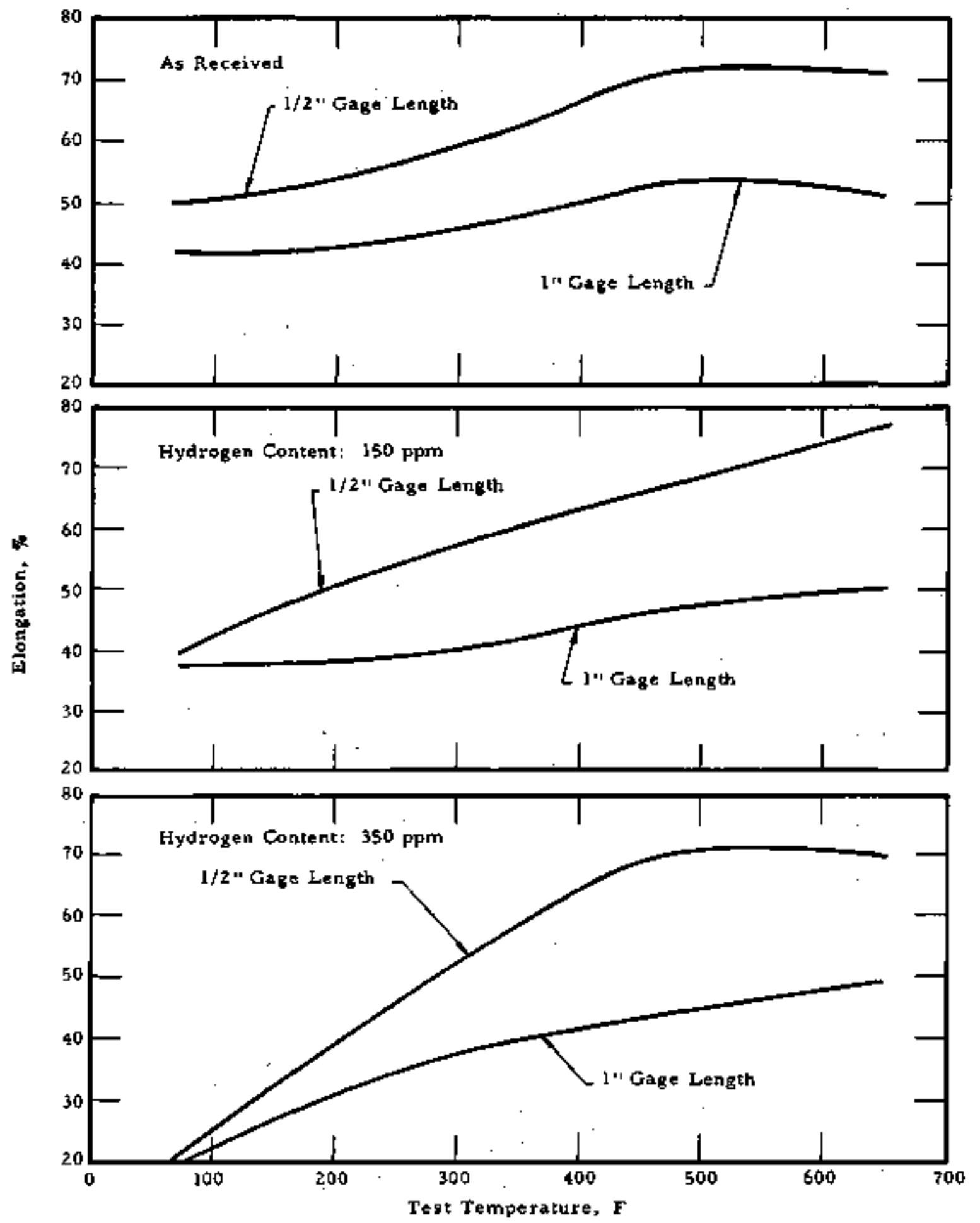


Figure 3-4. Tensile Strength of Cold-Worked Zircaloy-4 as a Function of Temperature

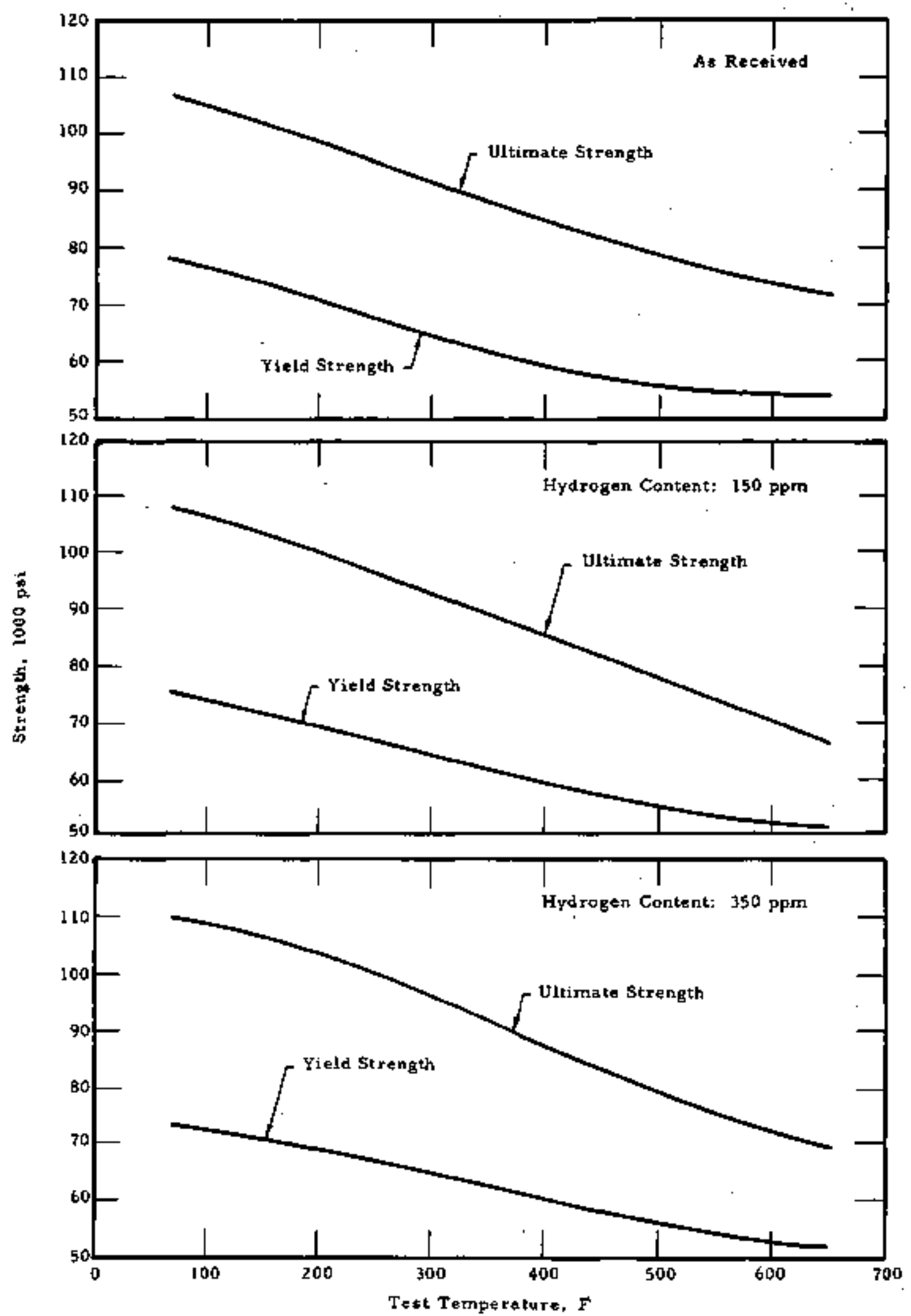


Figure 3-5. Elongation of Cold-Worked Zircaloy-4 as a Function of Temperature

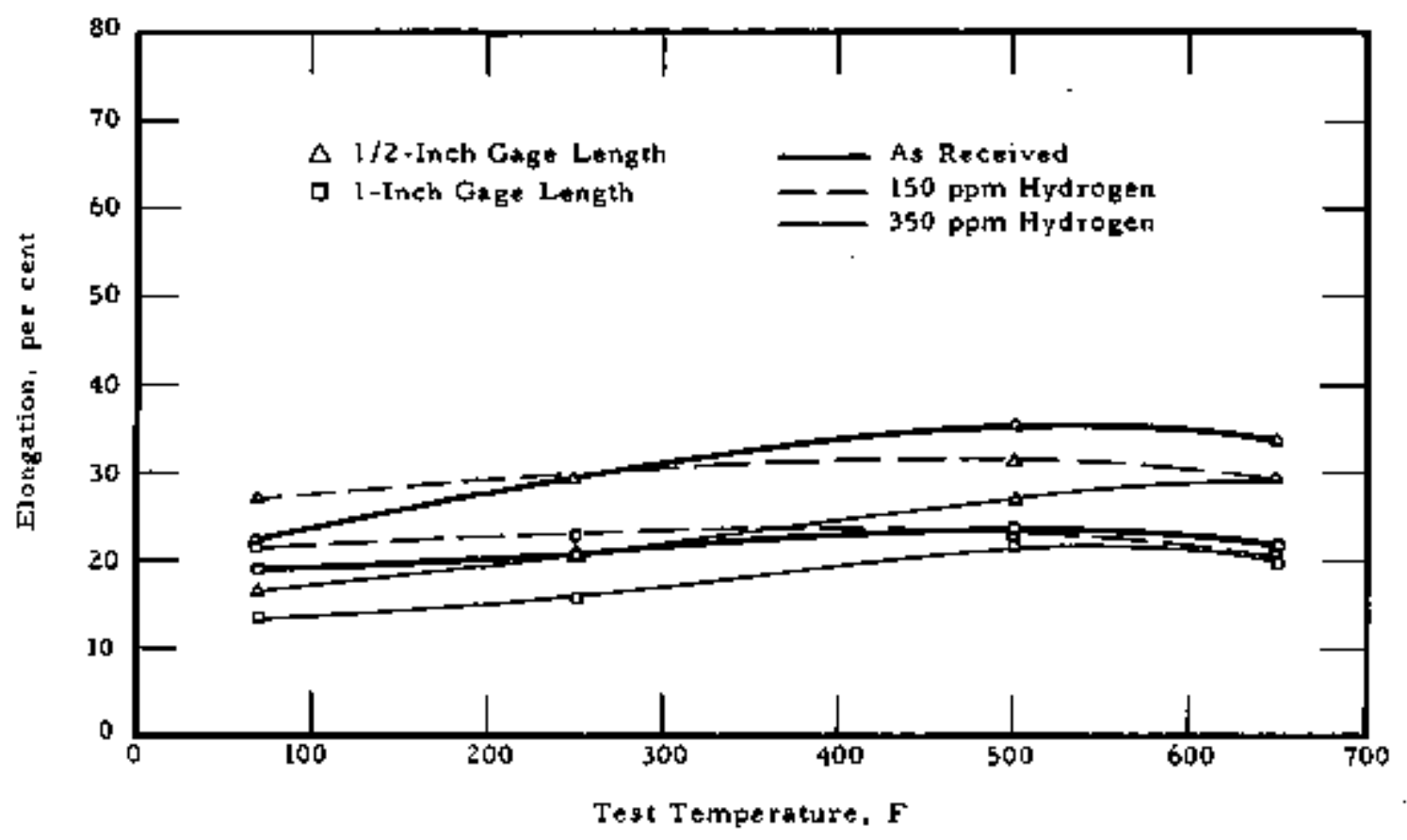




\section{REFERENCES}

J Koch, D. W., Ferguson, K. M., and Riskevics, K, F., Corrosion and Hydriding of Zircaloy-4 Under Heat Transfer Conditions in Pres surized Water, The Babcock \& Wilcox Company, Research Center Report No. 7730, Alliance, Ohio, September 1966.

2 Anderson, R. H., Jr., Harbinson, E. N., and Lowe, A. L., Jr., The Effect of Hydrogen on the Mechanical Properties of Zircaloy-4, The Babcock \& Wilcox Company, BAW-277, Lynchburg, Virginia, June 1965 .

3 Lynam, L. R., Metallurgical Examination of PWR Core 1 Blanket Fuel Rods at End of Third Seed Life, Westinghouse Atomic Fower Division, WAPD-TM-433, Pittsburgh, Pennsylvania, August 1964. 


\section{DISTRIBUTION}

1. U.S. Atomic Energy Commission (2I)

Brussels Office

APO, New York 09667

Attn: Senior AEC Representative

2. U.S. Atomic Energy Commission (2)

New York Operations Office

376 Hudson Street

New York, New York 10014

Attn: Leo Graup

Reports Library

3. U.S. Atomic Energy Commission

Brookhaven Area Office

New York Patents Group

Upton, New York 11973

Attr: Harmon S. Potter

4. U.S. Atomic Energy Commission Office of Foreign Activities, GM Washington, D.C. 20545

5. U.S. Atomic Energy Commission General Counsel for Patents

Washington, D.C. 20545

Attn: Roland Anderson

6. U.S.Atomic Energy Commission

Division of Technical Information Extension

P.O. Box 62

Oak Ridge, Tennessee 37830

7. U.S. Atomic Energy Commission (6)

Division of Reactor Development \& T echnology

Washington, D.C. 20545

Attn: J.M. Simmons

F. Kerze

D.E. Erb

A.N. Tardiff

S.A. Szawlewicz

M.A. Rosen

8. U.S. Atomic Energy Commission (2)

Division of Naval Reactors

Washington, D.C.

Attn: Robert H. Steele 
9. U. S. Atomic Energy Commission

Oak Ridge Operations Office

P. O. Box $\mathbf{E}$

Oak Ridge, Tennessee 37830

Attn: C. Matthew

10. U.S. Atomic Energy Commiasion (3)

Savannah River Laboratory

P. O. Box A

Aiken, South Carolina 29802

Attn: R. P, Marshall (2)

S. Rideout

11. U.S. Atomic Energy Commission

c/o Atomic Energy of Canada, Limited

Chalk River, Ontario, Canada

Attn: G. W. Perry

12. U. S, Atomic Energy Commission

c/o Whiteshell Nuclear Research

Establishment AECL

Pinawa, Manitoba, Canada

Attn: A. Sawatzsky

13. Oak Ridge National Laboratory (4)

Union Carbide Corporation

AEC Operations

P. O. Box X

Oak Ridge, Tennessee 37830

Attn: P. Patriarca

M. L. Picklesimer

J. E. Cunningham

P. L. Rittenhouse

14. Battelle Memorial Institute (5)

Pacific Northwest Labo ratory

P. O. Box 999

Richland, Washington 99352

Attn: J. J. Cadwell

R. Dillion

A. Bement.

R. G. Wheeler

Dr, D. de Halas

15. Argonne National Laboratory (2)

9700 South Cass Avenue

Argonne, Illinois 60439

Attn: S. Greenberg

J. E. Draley 
16. Atomics International

P. O. Box 309

Canoga Park, California 91304

Attn: C. E. Weber

17. Battelle Memorial Institute (2)

Columbus Laboratories

$505 \mathrm{King}$ Avenue

Columbus, Ohio 43201

Attn: 5. Paprocki

W. Berry

18. Westinghouse Electric Corporation (4)

Bettis Atomic Power Laboratory

P. O. Box 79

West Mifflin, Pennsylvania 15122

Attn: B. Lustman (2)

W. J. Babyak (2)

19. Combustion Engineering, Inc. (3)

Nuclear Division

Prospect Hill Road

Windaor, Connecticut 06095

Attn: S. S. Christopher

W. Che rnock

J. Tobin

20. General Electric Company (4)

Vallecitos Atomic Laboratory

P.O. Box 846

Pleasanton, California 94566

Attn: H. Klepfer (2)

K. Cohen (2)

21. Knolls Aconic Power Laboratory

P. O. Box 1072

Schenectady, New York 12301

Attn: A. E. Bibb

22. General Electric Company (2)

Nuclear Materials \& Propulsion Operation

P. O. Box 15132

Cincinnati, Ohio 45215

Attn: F. White

5. Naymark

23. Superior Tube Company Morristown, Pennsylvania

Attn: C. Matthews 
24. United Nuclear Corporation

5 New Street

White Plains, New York 10601

Attn: W. S. Mott

25. Westinghouse Electric Corporation (3)

Atomic Power Division

P. O. Box 355

Pittoburgh, Pennsylvania 15230

Attn: R. Allio (2)

P. G. DeHuff

26. Wah Chang Corporation

P. O. Box 460

Albany, Oregon 97321

Attn: S. Worchester

27. The Babcock \& $W$ ilcox Company (36)

Allen, RK/Alliance

Barringer, HS

Boyer, RL

Breazeale, $W M$

Central Files (6)

Deuster, RW

Esleeck, SH

Grant, SP

Holt, CD

Johns on, CR (2)

Jones, CE/Alliance

Koch, DW/Alliance (2)

Library, AED (2)
Littrell, LW (z)

Lowe, A.L, Jr. (2)

Lynch, ED

Poor, HH/Alliance

Probert, PB/Barberton

Rubright, MM/Alliance (2)

Schutt, PF

Swenson, HS/Alliance

Travis, CC/TRG

Trent, $C R$

Webb, RA, J r.

Whitaker, BW 